\title{
Comparative susceptibility of two Neotropical predators, Eriopis connexa and Chrysoperla externa, to acetamiprid and pyriproxyfen: Short and long-term effects after egg exposure ${ }^{\text {is }}$
}

\author{
Federico Rimoldi ${ }^{\text {a, }}$, Marilina N. Fogel ${ }^{\text {b, } 1}$, Alicia E. Ronco ${ }^{\text {a, }}$, Marcela I. Schneider ${ }^{\text {b, * }}$ \\ ${ }^{a}$ Centro de Investigaciones del Medio Ambiente (CIMA), Facultad de Ciencias Exactas, CONICET, Universidad Nacional de La Plata, Calle 47 y 115,1900 La \\ Plata, Buenos Aires, Argentina \\ ${ }^{\mathrm{b}}$ Laboratorio de Ecotoxicología: Plaguicidas y Control Biológico, Centro de Estudios Parasitológicos y de Vectores (CEPAVE-CONICET, Universidad Nacional \\ de La Plata), Boulevard 120 N $^{\circ} 1460$ entre 60 y 64, 1900 La Plata, Buenos Aires, Argentina
}

\section{A R T I C L E I N F O}

\section{Article history:}

Received 13 June 2017

Received in revised form

9 August 2017

Accepted 29 August 2017

\section{Keywords:}

Insecticides

Natural enemies

Comparative toxicity

Lethal and sub-lethal effects

\begin{abstract}
A B S T R A C T
Compatibility assessments between selective insecticides and the natural enemies of pests are essential for integrated-pest-management programs. Chrysoperla externa and Eriopis connexa are two principal Neotropical predators of agricultural pests whose conservation in agroecosystems requires a toxicity evaluation of pesticides to minimize the impact on those beneficial insects on the environment. The objective of this work was to evaluate the toxicity of the insecticides pyriproxyfen and acetamiprid on $C$. externa and E. connexa eggs exposed to the maximum recommended field concentrations of each along with three successive dilutions. The survival and the immature developmental time were assessed daily until adulthood and the mean survival time calculated over a 10-day period. The cumulative survival of E. connexa was reduced at all concentrations of both insecticides, while that of $C$. externa was significantly decreased by $\geq 50 \mathrm{mg} \mathrm{L}^{-1}$ of acetamiprid and $\geq 37.6 \mathrm{mg} \mathrm{L}^{-1}$ of pyriproxyfen. In both species, the reductions occurred principally on the eggs and first larval instar. Survival curves, in general, differed from those of the controls, with the mean survival time of $E$. connexa being significantly shorter in insecticides treatments than that of the controls. Certain concentrations of each of the insecticide lengthened the egg and first-larval-instar developmental periods of $E$. connexa and $C$. externa, respectively. Also, pyriproxyfen reduced the first-larval-instar period and lengthened the fourth of E. connexa. Acetamiprid was more toxic to E. connexa than to $C$. externa at the two highest concentrations. Conversely, at those same concentrations of pyriproxyfen, the relative toxicity to the two species was reversed. The present work represents the first investigation on the comparative susceptibility of two relevant Neotropical biological control agents to acetamiprid and pyriproxyfen. Also, it highlights the necessity of assessing long-term effects in the compatibility studies between natural enemies of agricultural pests and insecticides.
\end{abstract}

(C) 2017 Elsevier Ltd. All rights reserved.

\section{Introduction}

The use of broad-spectrum conventional insecticides to control agricultural pests has escalated worldwide since the 1950's (Sánchez-Bayo, 2011). The high toxicity of some of these compounds leads to adverse effects on nontarget organisms like fish,

\footnotetext{
This paper has been recommended for acceptance by Dr. Chen Da.

* Corresponding author.

E-mail addresses: frimoldi@quimica.unlp.edu.ar (F. Rimoldi), marilinafogel@ cepave.edu.ar (M.N. Fogel), mschneider@cepave.edu.ar (M.I. Schneider).

1 equal contribution.

2 died suddenly.
}

amphibians, microcrustaceans, vascular plants, and the natural enemies of agricultural pests-predators and parasitoids alike (Fogel et al., 2013, 2016; Rimoldi et al., 2008; Ronco et al., 2008; Schneider et al., 2004, 2009).

In recent decades, certain countries have implemented regulations to bring the use of pesticides closer to a more sustainable agriculture, according to the premises of integrated-pestmanagement (IPM) programs (European Commission, 2009) aimed at making the chemical control of pests compatible with their biological control by natural enemies. That goal requires the incorporation of new and more selective pesticides to improve the ecosystem service by conserving those nontarget species that participate in the natural control of pests (Jacas and Urbaneja, 2009). 
Within the framework of a more sustainable agriculture, new synthetic pesticides have been registered (Guedes et al., 2016). In many instances, these compounds have been considered as biorational on the basis of short term toxicity assessments with cosmopolitan or Nearctic and Palearctic species (FAO, 2013). The registration and utilization of those products in Argentina not requires the toxicity testing on native natural enemies (CASAFE, 2013/ 2015). An evaluation of the side effects of a novel pesticide on the local flora and fauna is highly relevant in order to ascertain the potential impact of that product on the productive systems of a given region, particularly when key biological control agents could be affected.

On the basis of the above criteria, pyriproxyfen and acetamiprid have accordingly become considered selective insecticides (Ishaaya et al., 2007; Moscardini et al., 2013; USEPA, 2015) and are thus commonly used on Argentine horticultural crops for controlling sap-sucking phytophagous pests.

Pyriproxyfen, an analog of the insect juvenile hormone, causes a marked suppression of embryogenesis, metamorphosis, and adult formation. Of molecular weight $321.5 \mathrm{~g} \mathrm{~mol}^{-1}$, the active ingredient exhibits a high octanol-water-partition coefficient ( $\log \mathrm{K}_{\mathrm{o} / \mathrm{w}} 5.37$ ), which lipophilicity facilitates the incorporation into organisms (Ghanim and Ishaaya, 2010; Sullivan and Goh, 2008).

Acetamiprid is a neonicotinoid insecticide that antagonizes the insect central nervous system through a specific interaction with nicotinic acetylcholine receptors to produce excitation, paralysis, and death (Tomizawa and Casida, 2005). Of molecular weight of $222.67 \mathrm{~g} \mathrm{~mol}^{-1}$, the active ingredient has an octanol-water-partition coefficient of $\log \mathrm{K}_{\mathrm{o} / \mathrm{w}}=0.8$. Recent research on the lethal and sublethal effects of this insecticide on beneficial organisms has led to a questioning of the compatibility of neonicotinoid pesticides like acetamiprid with beneficial insects (Christen et al., 2017; Fogel et al., 2013, 2016; He et al., 2012; Malagnoux et al., 2015).

Generalist arthropod predators are known worldwide as regulators of phytophagous arthropod populations (Symondson et al., 2002). Eriopis connexa Germar (Coleoptera: Coccinellidae) and Crysoperla externa Hagen (Neuroptera: Chrysopidae) are two beneficial Neotropical predators considered as potential biological agents for the control of different agricultural pests- $i$. e., aphids, whiteflies, mites, and thrips (Almeida-Sarmento et al., 2007; Fogel, 2012; Rimoldi, 2009; Rodrigues Barbosa et al., 2008). The conservation of $E$. connexa and $C$. externa in agroecosystems is, however, compromised by the indiscriminate application of pesticides. Therefore, the development, introduction, and application of new reduced-risk chemicals are critical to conserve these beneficial organisms in agroecosystems.

Conversely, an additional relevant criterion for selecting biological control agents concerns their susceptibility to pesticides since a high tolerance or resistance would result in better fitness upon possible exposure. Hence, information on the relative susceptibility to insecticides among different natural enemies of pests would be an aid to decision-making when selecting biological control agents in IMP programs. Studies on the compatibility between insecticides and natural enemies, however, are mainly oriented towards the assessment of effects when products are exposed to the developmental stages at which the organisms control the pest (i. e., the predatory phase); but, the analysis should take into account the entire life history of a pest predator-i. $e$., the protected stages like eggs or pupae along with the adult stage that in some species is not predatory such as Chrysopidae species. Previous studies have been done on only certain development stages (Fogel et al., 2016; Rimoldi et al., 2008, 2012) but any comparative studies have not been conducted regarding to the susceptibility of predators species to pesticides.
Within this context, the purpose of the study was to evaluate under laboratory conditions both the short- and long-term effects of acetamiprid and pyriproxyfen on the two beneficial Neotropical predators, $C$. externa and E. connexa, after exposure of their eggs to pyriproxyfen and acetamiprid. Besides, the comparative susceptibility of both species to both insecticides was assessed.

\section{Materials and methods}

\subsection{Origin and maintenance of the organisms}

Predators colonies were initiated and established from adults collected on horticultural crops of the La Plata region, Argentina ( $34^{\circ} 57^{\prime} 17^{\prime \prime} \mathrm{S}, 57^{\circ} 53^{\prime} 26^{\prime \prime} \mathrm{W}$ ). After quarantining, the individuals were maintained in the laboratory and housed for multiplication under controlled environmental conditions (temperature, $25 \pm 2{ }^{\circ} \mathrm{C}$; relative humidity, $75 \pm 5 \%$; and photoperiod, 16:8-h light:dark), according to pre-established protocols (Fogel, 2012; Rimoldi, 2009). Every year the colonies were infused with wild stock collected from the same geographical origin, in order to maintain genetic variability. In the bioassays, insect cohorts from the laboratory colonies were used.

Chrysoperla externa larvae were fed with Sitrotoga cerealella Olivier (Lepidoptera: Gelechiidae) eggs ad libitum as a "factitious prey" and provided by the insectaria IMYZA-Castelar, Argentina, while adults were fed with an artificial diet according to Nuñez (1998). Eriopis connexa larvae and adults were fed with the birdcherry aphid Rhopalosiphum padi L. (Hemiptera: Aphididae) ad libitum (Fogel, 2012), and an artificial diet was added as a nutritional supplement (Haramboure et al., 2016).

The bioassays were carried out in a growth chamber under the same controlled environmental conditions as those mentioned above.

\subsection{Insecticides}

Commercial formulated insecticides were used in the bioassays: Epingle $^{\circledR}(10 \%[w / v]$ pyriproxyfen; Summit-Agro, Buenos Aires, Argentina), and Mospilan ${ }^{\circledR}$ (acetamiprid 20\% [w/w]; Summit-Agro, Buenos Aires, Argentina). For each insecticide the maximum recommended field concentrations (MRFCs) registered in Argentina (CASAFE, 2013/2015) was used along with the dilutions corresponding to 50,25 , and $12.5 \%$. Therefore, the respective concentrations applied, when expressed as the concentration of active ingredient (a.i.), were: for pyriproxyfen $75,37.6,18.7$, and $9.4 \mathrm{mg}$ a.i. $\mathrm{L}^{-1}$ and for acetamiprid $200,100,50$, and $25 \mathrm{mg}$ a.i. $\mathrm{L}^{-1}$.

\subsection{Bioassays}

The bioassays were done in eggs where embryos of both species have a similar development and drying of the proteinaceous chorion that wrap eggs.

Less than 24-h-old C. externa eggs were exposed by dipping for $15 \mathrm{~s}$ into each insecticide concentration to be tested. Thereafter the eggs were placed individually in plastic Petri dishes $(9 \mathrm{~cm}$ diameter, $1.3 \mathrm{~cm}$ depth), and the emerged larvae were fed ad libitum on S. cerealella eggs following the protocols in Rimoldi et al. (2008).

For the E. connexa experiments, 48-h-old eggs were exposed by dipping for $15 \mathrm{~s}$ in each insecticide concentration. The controls of each species were dipped in distilled water. The emerged larvae of E. connexa were placed individually in plastic Petri dishes $(9 \mathrm{~cm}$ diameter, $1.3 \mathrm{~cm}$ depth) to avoid cannibalism and fed ad libitum with the same food used for rearing the colonies.

At the time of exposure, the embryos were under development inside the eggs of both predator species. Each treatment consisted 
in three replications, though the number of individuals per replication was variable, in all instances, a minimum of 10 was maintained. For $C$. externa the total number of exposed eggs in each treatment $(n)$ was from 32 to 61 , while to E. connexa the $n$ was from 77 to 228 individuals (this specie lay eggs in batches).

Every $24 \mathrm{~h}$, and until each species reached the adult stage, the effects of the insecticides on different life parameters, were assessed: immature developmental time (in the instars or stages where survival was greater than 30\%) and survivorship (both the cumulative survival-i.e., the total number of adults emerging from the exposed eggs-and the survival at each developmental stage-i. e., egg, larva, pupa). The survival probability was also analyzed, taking into account the first 10 days after egg exposure, along with the mean survival time.

The relative susceptibility to the two insecticides between E. connexa and C. externa was assessed from the cumulative survival at all concentrations of each insecticide, whereas the survival curves were calculated from only the data corresponding to treatment at the two MRFCs (200 mg a.i. $\mathrm{L}^{-1}$ of acetamiprid and $75 \mathrm{mg}$ a.i..$^{-1}$ of pyriproxyfen).

\subsection{Statistical analysis}

The results are presented as the mean \pm standard error. The Shapiro-Wilk's test was employed to assess the distribution of the data. If the data had a normal distribution, the one-way analysis of variance (ANOVA) was used to observe differences between the treatments. When the proportional data required normalization, the arc-sine square-root transformation was done before analysis. After the ANOVA, the means were separated by applying the leastsignificant-difference (LSD) test to assess differences among treatments $(\alpha \leq 0.05)$. The Kruskal-Wallis test was used for the set of data not reaching normality, and in this circumstance the Dunn test was used for multiple pairwise comparisons. The analysis of survival during the first 10 days after exposure was used to determine the mean survival time in each treatment. The survival functions were estimated by the Kaplan-Meier method along with the log-rank test for treatment comparisons, through the use of the Bonferroni correction for paired comparisons between treatments. In the comparisons between species, the data were corrected to the control values through the use of the Abbott correction. The XLStat program (Addinsoft XLstat for Excel, Paris, France. 2009. http:// xlstat.softonic.com) was used for the analysis.

\section{Results}

\subsection{Effects of insecticides on Chrysoperla externa}

The insecticides reduced the cumulative survival of $C$. externa significantly from concentrations of $50 \mathrm{mg}$ a.i. $\mathrm{L}^{-1}$ acetamiprid and $37.6 \mathrm{mg}$ a.i. $\mathrm{L}^{-1}$ pyriproxyfen $(\mathrm{F}=3.132 ; \mathrm{df}=8,18 ; p=0.021)$ (Table 1). The analysis of the survival at each developmental stage indicated that the eggs and first larval instars were more susceptible to the insecticides than the later stages. Acetamiprid caused a significant decrease in the survival of those two stages at $200 \mathrm{mg}$ a.i. $\mathrm{L}^{-1}$, whereas the insecticide was also toxic to the first larval instar at 100 and $25 \mathrm{mg}$ a.i. $\mathrm{L}^{-1}(\mathrm{~F}=3.186 ; \mathrm{df}=8,18 ; p=0.020$ eggs and $\mathrm{F}=4.545 ; \mathrm{df}=8,18 ; p=0.004$ first larval instar).

In contrast, pyriproxyfen at $75 \mathrm{mg}$ a.i. $\mathrm{L}^{-1}$ significantly reduced the survival of eggs $(\mathrm{F}=3.186$; $\mathrm{df}=8,18 ; p=0.020)$; whereas at 75 , 37.6 , and $18.7 \mathrm{mg}$ a.i. $\mathrm{L}^{-1}$ the pesticide decreased the survival of the first larval instar $(\mathrm{F}=4.545$; $\mathrm{df}=8,18 ; p=0.004)$. No significant effects on the survival of the second and third larval instars or on the pupal stage were detected in any of treatments tested (Table 1 ) $(\mathrm{K}=7.741 ; \mathrm{df}=8,18 ; p=0.459 . \mathrm{F}=1.081 ; \mathrm{df}=8,18 ; p=0.419$. $\mathrm{K}=7.317 ; \mathrm{df}=8,18 ; p=0.503)$.

The survival pattern of $C$. externa during the 10 days after insecticide exposure provides information on the rapidity of the action of those compounds. In all the acetamiprid treatments and after exposure to pyriproxyfen at $75,37.6$, and $9.4 \mathrm{mg}$ a.i.. $\mathrm{L}^{-1}$ a difference in the survival curves occurred with respect to those of the controls (Fig. 1a and b) (Long-rank $=62.837$; $p<0.0001$ ). The mean survival time of $C$. externa, however, was reduced significantly with respect to the control values only at $200 \mathrm{mg}$ a.i. $\mathrm{L}^{-1}$ of acetamiprid and at $75 \mathrm{mg}$ a.i. $\mathrm{L}^{-1}$ of pyriproxyfen (MRFCs) (Table 3). When we compared the corrected survival curves for the MRFCs of each insecticide, we observed that acetamiprid and pyriproxyfen produced similar profiles for the survival of $C$. externa (Fig. 1c) (Long-rank $=0.015 ; p=0.902$ ).

Acetamiprid at $50 \mathrm{mg}$ a.i. $\mathrm{L}^{-1}$ and pyriproxyfen at $9.4 \mathrm{mg}$ a.i. $\mathrm{L}^{-1}$ significantly lengthened the duration of the first larval-instar period with respect to the control time of $3.71 \pm 0.27$ days by $1.25 \pm 0.19$ and $1.35 \pm 0.32$ days, respectively $(\mathrm{F}=6.371 ; \mathrm{df}=6,14$; $p<0.001$ ). Nevertheless, in these treatments, no significant effects on the rest of developmental stages were observed. The other pesticide concentrations did not produce significant effects on any of developmental stages tested $(\mathrm{F}=2.364 ; \mathrm{df}=8,18 ; p=0.062$

Table 1

Toxicity of acetamiprid and pyriproxyfen on the survival of immature stages of Chrysoperla externa. The data correspond to mean values ( \pm SEM).

\begin{tabular}{|c|c|c|c|c|c|c|c|}
\hline \multirow[t]{3}{*}{ Treatments } & \multirow{3}{*}{$\begin{array}{l}\text { Concentration } \\
\text { (mg a.i./L) }\end{array}$} & \multicolumn{6}{|l|}{ Survival (\%) } \\
\hline & & \multirow[t]{2}{*}{ Eggs $^{a}$} & \multicolumn{3}{|l|}{ Larval } & \multirow[t]{2}{*}{ Pupal $^{\text {b }}$} & \multirow[t]{2}{*}{ Cumulative survival $^{\mathrm{a} d}$} \\
\hline & & & $1 \mathrm{st}^{\mathrm{a}}$ & $2 \mathrm{nd}^{\mathrm{b}}$ & $3 \mathrm{rd}^{\mathrm{a}}$ & & \\
\hline Control & & $88.24 \pm 6.79 a b c$ & $74.89 \pm 7.30 a$ & $94.87 \pm 2.56$ & $83.33 \pm 8.33$ & $94.44 \pm 5.56$ & $49.02 \pm 7.07 a$ \\
\hline \multirow[t]{4}{*}{ Acetamiprid } & $200^{c}$ & $60.44 \pm 8.79 d$ & $31.48 \pm 8.07 \mathrm{~cd}$ & $88.89 \pm 11.11$ & $91.67 \pm 8.33$ & $72.22 \pm 14.70$ & $10.07 \pm 2.66 d$ \\
\hline & 100 & $95.05 \pm 2.48 a$ & $43.38 \pm 3.44 \mathbf{b c d}$ & $75.24 \pm 7.80$ & $83.33 \pm 9.62$ & $78.33 \pm 11.67$ & $19.60 \pm 2.70 \mathrm{bcd}$ \\
\hline & 50 & $65.76 \pm 15.89 \mathrm{~cd}$ & $63.81 \pm 6.92 \mathrm{ab}$ & $73.81 \pm 14.48$ & $86.67 \pm 13.33$ & $88.89 \pm 11.11$ & $25.76 \pm 12.40 \mathrm{bcd}$ \\
\hline & 25 & $72.42 \pm 8.79 b c d$ & $51.85 \pm 4.52 \mathbf{b c}$ & $93.33 \pm 6.67$ & $100.00 \pm 0.00$ & $80.56 \pm 10.02$ & $28.18 \pm 5.33 a b c$ \\
\hline \multirow[t]{4}{*}{ Pyriproxyfen } & $75^{c}$ & $57.30 \pm 3.69 d$ & $30.94 \pm 8.53 \mathbf{d}$ & $94.44 \pm 5.56$ & $100.00 \pm 0.00$ & $83.33 \pm 16.67$ & $14.60 \pm 5.43 \mathbf{c d}$ \\
\hline & 37.6 & $88.06 \pm 4.80 a b c$ & $47.78 \pm 10.60 \mathrm{bcd}$ & $86.11 \pm 7.35$ & $80.11 \pm 5.04$ & $72.50 \pm 5.20$ & $20.11 \pm 3.13$ bcd \\
\hline & 18.7 & $91.67 \pm 4.81 \mathrm{ab}$ & $51.82 \pm 4.30 \mathbf{b c}$ & $88.89 \pm 11.11$ & $93.33 \pm 6.67$ & $86.11 \pm 7.35$ & $33.33 \pm 4.81 \mathrm{ab}$ \\
\hline & 9.4 & $70.73 \pm 7.62 \mathrm{bcd}$ & $63.54 \pm 4.58 \mathrm{ab}$ & $100.00 \pm 0.00$ & $75.24 \pm 18.10$ & $100.00 \pm 0.00$ & $34.40 \pm 9.60 \mathrm{ab}$ \\
\hline \multirow{3}{*}{$\alpha<0.05$} & & $\mathrm{~F}=3.186$ & $\mathrm{~F}=4.545$ & $\mathrm{~K}=7.741$ & $\mathrm{~F}=1.081$ & $\mathrm{~K}=7.317$ & $\mathrm{~F}=3.132$ \\
\hline & & $p=0.020$ & $p=0.004$ & $p=0.459$ & $p=0.419$ & $p=0.503$ & $p=0.021$ \\
\hline & & $\mathrm{df}=8 ; 18$ & $\mathrm{df}=8 ; 18$ & $\mathrm{df}=8 ; 18$ & $\mathrm{df}=8 ; 18$ & $\mathrm{df}=8 ; 18$ & $\mathrm{df}=8 ; 18$ \\
\hline
\end{tabular}

Letters in bold font indicate significant differences respect to control.

a One-way ANOVA test. Means were separated by a least significant difference (LSD) multiple range test $(p \leq 0.05)$.

b Kruskal-Wallis test. Dunn test was used to multiple pairwise comparisons $(p \leq 0.05)$.

c Maximum recommended field concentration.

d Number of adults respect to exposed eggs. 
A

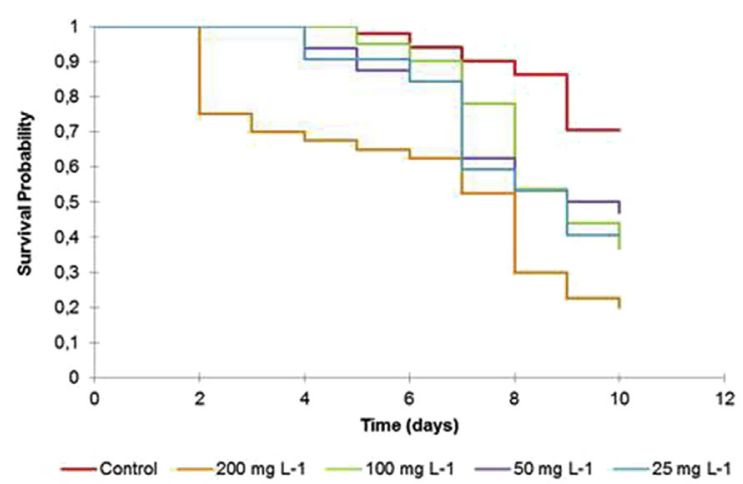

B

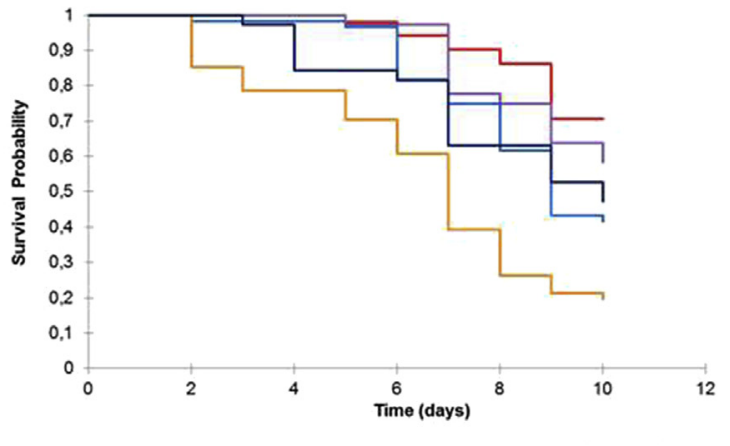

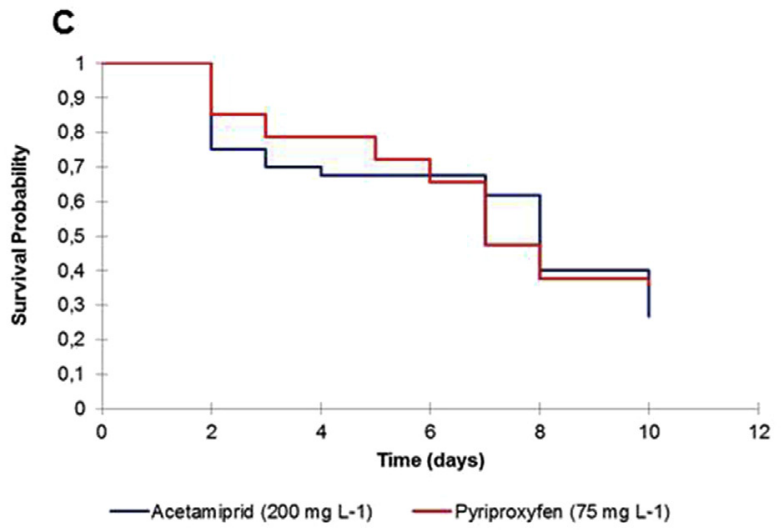

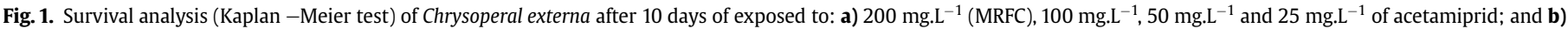

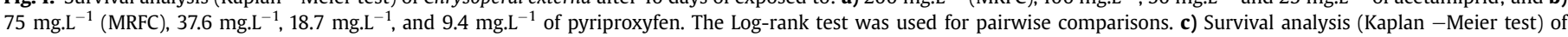

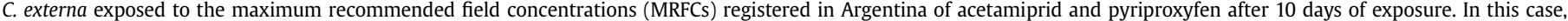
survival data were corrected with control to be possible the comparison.

eggs. $\mathrm{F}=1.057 ; \mathrm{df}=4,10 ; p=0.426$ second larval instar. $\mathrm{F}=0.818$; $\mathrm{df}=2,6 ; p=0.485$ third larval instar. $\mathrm{F}=2.363 ; \mathrm{df}=1,4 ; p=0.199$ pupal stage).

\subsection{Effects of insecticides on E. connexa}

Acetamiprid and pyriproxyfen at all concentrations tested significantly reduced the cumulative survival of $E$. connexa from the egg to the adult stage (Table 2$)(\mathrm{F}=16.741 ; \mathrm{df}=8,18 ; p<0.0001)$. An analysis the survival of each developmental stage indicated that acetamiprid reduced egg survival at the highest concentration (200 mg a.i. $\left.\mathrm{L}^{-1}\right)(\mathrm{K}=19.207 ; \mathrm{df}=8,18 ; p=0.014)$, but decreased the survival of first larval instar both at that maximal concentration $\left(200 \mathrm{mg}\right.$ a.i. $\left.\mathrm{L}^{-1}\right)$ and at the half-maximal (100 $\mathrm{mg}$ a.i. $\left.\mathrm{L}^{-1}\right)$ $(\mathrm{K}=22.948 ; \mathrm{df}=8,18 ; p=0.003)$. In contrast, pyriproxyfen did not affect survival at any concentration, nor did acetamiprid at $50 \mathrm{mg}$ a.i. $\mathrm{L}^{-1}$ or $25 \mathrm{mg}$ a.i. $\mathrm{L}^{-1}$ altered the survival of any developmental stage $(\mathrm{K}=15.705 ; \mathrm{df}=7,16 ; p=0.280$ second larval instar. $\mathrm{K}=8.449 ; \mathrm{df}=7,16 ; p=0.459$ third larval instar. $\mathrm{K}=3.478 ; \mathrm{df}=7$, $16 ; p=0.838$ fourth larval instar. $\mathrm{F}=0.476 ; \mathrm{df}=7,16 ; p=0.838$ pupal stage). Nevertheless, these partial mortalities, though not in themselves statistically significant, determined the significant reductions in cumulative survival relative to the control values (Table 2).

In all the insecticide treatments, the survival curves of $E$. connexa differed significantly from those of the controls (Fig. 2a and b), thus demonstrating that survival probability of this predator became compromised (Long-rank $=365.920 ; p<0.0001$ ). Moreover, in all instances the mean survival times estimated were significantly lower than those of the control group (Table 3 ).

As to a comparison of the selectivity between both insecticides at the respective MRFCs (200 mg a.i. $\mathrm{L}^{-1}$ of acetamiprid and $75 \mathrm{mg}$ a.i. $\mathrm{L}^{-1}$ of pyriproxyfen) in terms of the toxicity to $E$. connexa, acetamiprid caused a much higher mortality than did pyriproxyfen. Furthermore, acetamiprid treatment resulted in curves with more pronounced slopes than those of pyriproxyfen, thus evidencing a more rapid action (Fig. 2c) (Long-rank $=90.202 ; p<0.0001$ ).

Pyriproxyfen at 75 and $37.6 \mathrm{mg}$ a.i. $\mathrm{L}^{-1}$ and acetamiprid at $100 \mathrm{mg}$ a.i. $\mathrm{L}^{-1}$ lengthened the duration of the egg stage relative to the control period ( $4.00 \pm 0.01$ days $)$ by $0.4 \pm 0.07,0.23 \pm 0.03$, and $0.25 \pm 0.09$ days, respectively $(\mathrm{F}=5.913 ; \mathrm{df}=7,16 ; p=0.002)$. Moreover, pyriproxyfen at those two highest concentrations also shortened the first larval-instar period relative to the control time of $2.45 \pm 0.01$ days by $0.26 \pm 0.1$ and $0.33 \pm 0.1$ days, respectively $(\mathrm{F}=7.971 ; \mathrm{df}=6,14 ; p=0.001)$. This insecticide at $75 \mathrm{mg}$ a.i. $\mathrm{L}^{-1}$ lengthened the duration of third larval instar respect to the controls $(3.98 \pm 0.08$ days $)$ by $0.5 \pm 0.28$ days $(F=7.059 ; \mathrm{df}=6,14$; $p=0.001$ ). The rest of the treatments did not cause any significant effect on the developmental time of other instars or stages $(\mathrm{F}=1584 ; \mathrm{df}=6,14 ; p=0.224$ second larval instar. $\mathrm{F}=1.791$; $\mathrm{df}=6,14 ; p=0.173$ fourth larval instar. $\mathrm{F}=0.685 ; \mathrm{df}=4,10$; $p=0.618$ pupal stage). 
Table 2

Toxicity of acetamiprid and pyriproxyfen on the survival of immature stages of Eriopis connexa. The data correspond to mean values ( \pm SEM).

\begin{tabular}{|c|c|c|c|c|c|c|c|c|}
\hline \multirow[t]{3}{*}{ Treatments } & \multirow{3}{*}{$\begin{array}{l}\text { Concentration } \\
\text { (mg a.i.L-1) }\end{array}$} & \multicolumn{7}{|l|}{ Survival (\%) } \\
\hline & & \multirow[t]{2}{*}{ Eggs $^{b}$} & \multicolumn{4}{|l|}{ Larval } & \multirow[t]{2}{*}{ Pupal $^{1}$} & \multirow[t]{2}{*}{ Cumulative survival $^{\mathrm{a} d}$} \\
\hline & & & $1 \mathrm{st}^{\mathrm{b}}$ & $2 \mathrm{nd}^{\mathrm{b}}$ & $3 \mathrm{rd}^{\mathrm{b}}$ & $4 \mathrm{th}^{\mathrm{b}}$ & & \\
\hline \multirow{5}{*}{$\begin{array}{l}\text { Control } \\
\text { Acetamiprid }\end{array}$} & & $85.53 \pm 2.01 \mathrm{a}$ & $92.34 \pm 0.72 a$ & $94.94 \pm 2.02$ & $98.80 \pm 0.60$ & $91.45 \pm 2.59$ & $82.49 \pm 1.98$ & $55.88 \pm 2.87 a$ \\
\hline & $200^{c}$ & $6.41 \pm 3.39 \mathbf{b}$ & $0.00 \pm 0.00 \mathbf{b}$ & & & & & $0.00 \pm 0.00 \mathbf{e}$ \\
\hline & 100 & $68.39 \pm 9.25 a b$ & $32.44 \pm 7.01 \mathbf{b}$ & $100.00 \pm 0.00$ & $100.00 \pm 0.00$ & $90.00 \pm 10.00$ & $76.19 \pm 12.60$ & $13.92 \pm 1.89 \mathbf{d}$ \\
\hline & 50 & $71.18 \pm 3.60 \mathrm{ab}$ & $79.50 \pm 6.74 a b$ & $100.00 \pm 0.00$ & $100.00 \pm 0.00$ & $91.38 \pm 5.27$ & $79.07 \pm 4.93$ & $40.41 \pm 3.03 \mathbf{b}$ \\
\hline & 25 & $57.58 \pm 3.03 a b$ & $77.51 \pm 5.69 a b$ & $100.00 \pm 0.00$ & $100.00 \pm 0.00$ & $70.00 \pm 15.28$ & $82.22 \pm 9.69$ & $25.15 \pm 5.61 \mathbf{c d}$ \\
\hline \multirow[t]{4}{*}{ Pyriproxyfen } & $75^{c}$ & $84.76 \pm 5.92 \mathrm{a}$ & $53.65 \pm 4.84 a b$ & $100.00 \pm 0.00$ & $96.97 \pm 3.03$ & $85.86 \pm 9.99$ & $90.00 \pm 5.77$ & $32.91 \pm 1.13 \mathbf{b c}$ \\
\hline & 37.6 & $73.29 \pm 4.42 \mathrm{ab}$ & $57.84 \pm 2.60 \mathrm{ab}$ & $95.66 \pm 2.20$ & $97.44 \pm 2.56$ & $84.47 \pm 4.84$ & $94.29 \pm 2.97$ & $31.46 \pm 3.42 \mathbf{b c}$ \\
\hline & 18.7 & $59.95 \pm 8.69 a b$ & $79.01 \pm 2.83 \mathrm{ab}$ & $93.89 \pm 3.09$ & $100.00 \pm 0.00$ & $91.67 \pm 8.33$ & $77.78 \pm 11.11$ & $30.27 \pm 2.17 \mathbf{b c}$ \\
\hline & 9.4 & $59.92 \pm 3.04 a b$ & $62.18 \pm 4.23 \mathrm{ab}$ & $100.00 \pm 0.00$ & $100.00 \pm 0.00$ & $88.89 \pm 11.11$ & $79.17 \pm 15.02$ & $27.33 \pm 7.85 c$ \\
\hline \multirow[t]{3}{*}{$\alpha<0.05$} & & $K=19.207$ & $\mathrm{~K}=22.948$ & $\mathrm{~K}=15.705$ & $\mathrm{~K}=8.449$ & $\mathrm{~K}=3.478$ & $\mathrm{~F}=0.476$ & $\mathrm{~F}=16.741$ \\
\hline & & $p=0.014$ & $p=0.003$ & $p=0.280$ & $p=0.459$ & $p=0.838$ & $p=0.838$ & $p<0.0001$ \\
\hline & & $d f=8 ; 18$ & $d f=8 ; 18$ & $d f=7 ; 16$ & $d f=7 ; 16$ & $d f=7 ; 16$ & $d f=7 ; 16$ & $d f=8 ; 18$ \\
\hline
\end{tabular}

Letters in bold font indicate significant differences respect to control.

a One-way ANOVA test. Means were separated by a least significant difference (LSD) multiple range test $(p \leq 0.05)$.

b Kruskal-Wallis test. Dunn test was used to multiple pairwise comparisons $(p \leq 0.05)$.

c Maximum recommended field concentration.

d Number of adults respect to exposed eggs.

Table 3

Mean survival time estimated from survival analysis, for Chrysoperla externa and Eriopis connexa exposed to several concentrations of acetamiprid, pyriproxyfen and distilled water (control). The data correspond to mean values ( \pm SEM).

\begin{tabular}{llll}
\hline \multirow{2}{*}{$\begin{array}{l}\text { Treatments } \\
\text { (mg a.i./L) }\end{array}$} & & \multicolumn{2}{l}{ Mean survival time* } \\
\cline { 3 - 4 } & & Chrysoperla externa & Eriopis connexa \\
\hline Control & & $8.686 \pm 0.127$ & $7.741 \pm 0.159$ \\
Acetamiprid & 200 & $6.450 \pm 0.499^{*}$ & $2.104 \pm 0.051^{*}$ \\
& 100 & $8.610 \pm 0.238$ & $3.686 \pm 0.158^{*}$ \\
& 50 & $8.313 \pm 0.357$ & $3.438 \pm 0.088^{*}$ \\
Pyriproxyfen & 25 & $7.781 \pm 0.286$ & $4.370 \pm 0.105^{*}$ \\
& 75 & $6.607 \pm 0.348^{*}$ & $3.725 \pm 0.124^{*}$ \\
& 37.6 & $8.533 \pm 0.229$ & $5.299 \pm 0.244^{*}$ \\
& 18.7 & $9.111 \pm 0.236$ & $5.485 \pm 0.231^{*}$ \\
& 9.4 & $8.263 \pm 0.379$ & $4.231 \pm 0.197^{*}$ \\
\hline
\end{tabular}

*Indicate significant differences respect to Control.

\subsection{Comparative susceptibility of E. connexa and C. externa to acetamiprid and pyriproxyfen}

An analysis of the cumulative mortality indicated a differential relative susceptibility on the part of the two species to the insecticides, but only at concentrations of $100 \%$ or $50 \%$ of the MFRCs (acetamiprid $U=9.00 ; p=0.037-200 \mathrm{mg}$ a.i. $\mathrm{L}^{-1} \cdot \mathrm{Z}=-2.364$; $p=0.018-100 \mathrm{mg}$ a.i. $\mathrm{L}^{-1} . \mathrm{Z}=0.837 ; p=0.402-50 \mathrm{mg}$ a.i. $\mathrm{L}^{-1} . \mathrm{Z}=-$ $0.949 ; \quad p=0.343-25 \mathrm{mg}$ a.i. $\mathrm{L}^{-1}$. Pyriproxyfen $\mathrm{Z}=2.491$; $p=0.013-75 \mathrm{mg}$ a.i. $\mathrm{L}^{-1} . \mathrm{Z}=1.969 ; p=0.049-37.6 \mathrm{mg}$ a.i. $\mathrm{L}^{-1}$. $\mathrm{Z}=-1.385 ; p=0.166-18.7 \mathrm{mg}$ a.i. $\mathrm{L}^{-1} \cdot \mathrm{Z}=-0.924$; $p=0.355-9.4 \mathrm{mg}$ a.i. $\left.\mathrm{L}^{-1}\right)$. Whereas, at those concentrations E. connexa was more susceptible to acetamiprid than $C$. externa whereas E. connexa was less susceptible to pyriproxyfen than C. externa (Fig. 3).

The survival patterns for both predators during the 10 consecutive days after exposure to the insecticides revealed that E. connexa was more susceptible than $C$. externa to acetamiprid (Fig. 4a) (Long-rank $=65.407 ; p<0.0001$ ). Moreover, the estimation of mean survival times (corrected respect to control) for this insecticide, were different for the two species-i. e., 6.1 days (5.2-6.9) for $C$. externa and 2.2 days (2.0-2.3) for E. connexa. The survival curves of both predators after exposure to pyriproxyfen furthermore demonstrated significant differences with this insecticide (Fig. 4b), though here stronger toxic effects were observed with $C$. externa (Long-rank $=4.659 ; p=0.031$ ). Nevertheless, the mean survival times recorded with both predators for this insecticide were quite similar at $6.9(6.2-7.6)$ days with $E$. connexa and at 7.0 (6.3-7.8) days with C. externa.

\section{Discussion}

Compatibility studies between insecticides and natural enemies of agricultural pests have indicated that the differential toxicity of pesticides to beneficial insects depends mainly of the route of exposure and the developmental stage of the individuals exposed (Desneux et al., 2007; Fogel et al., 2013, 2016; Moscardini et al., 2013; Rimoldi, 2009; Rimoldi et al., 2008, 2012; Youn et al., 2003). The present study has focused on the comparative toxicity to two relevant Neotropical pest predators, E. connexa and C. externa, of the insecticides acetamiprid and pyriproxyfen, those being commonly used to control agricultural pests in Argentina.

\subsection{Effects on egg survival}

The eggs and the first larval instars of both species exhibited a high susceptibility to acetamiprid, especially at the two highest concentrations, where survival was substantially affected, with E. connexa being more susceptible than $C$. externa. This greater susceptibility of E. connexa eggs to insecticides than those of C. externa had been similarly cited previously for the neurotoxic insecticide cypermethrin. This latter insecticide was toxic to the eggs or embryos of E. connexa (Fogel, 2012), but was harmless to the eggs or embryos of $C$. externa (Rimoldi et al., 2008).

Moreover, the high toxicity of acetamiprid on the eggs of E. connexa previously reported by Fogel et al. (2013) agrees with other studies on Coccinelidae species, such as Harmonia axyridis Pallas (Coleoptera: Coccinellidae) (Mirande, 2016; Youn et al. 2003). Several reports have cited the ovicidal effects of various pesticides on chrysopids (Ferreira et al., 2005; Silva et al., 2012). In particular, Ayuvi et al. (2013) reported similar toxic effects of the neonicotinoids imidacloprid and thiamethoxam on Chrysoperla carnea Stephens (Neuroptera: Chrysopidae).

In the present study, pyriproxyfen reduced the survival of eggs and first larval instars of $C$. externa, though no mortality was observed in those same stages of $E$. connexa. Although most insectgrowth regulators (IGRs) do not usually affect the egg survival of the natural enemies of pests (Medina et al., 2003; Rill et al., 2008; 
A

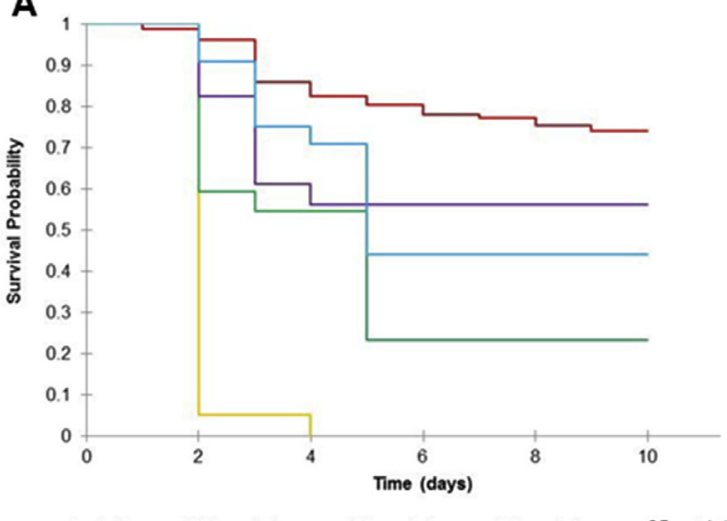

- Control $-200 \mathrm{mg} \mathrm{L}+1-100 \mathrm{mg} \mathrm{L}^{-1}-50 \mathrm{mg} \mathrm{L}^{-1}-25 \mathrm{mg} \mathrm{L}^{-1}$
B

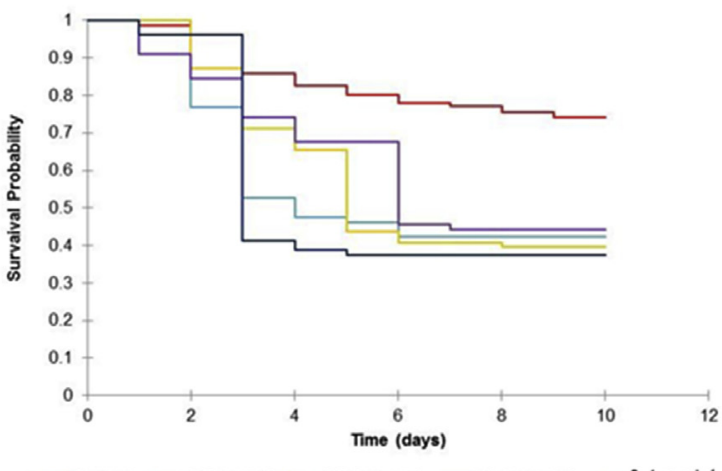

C

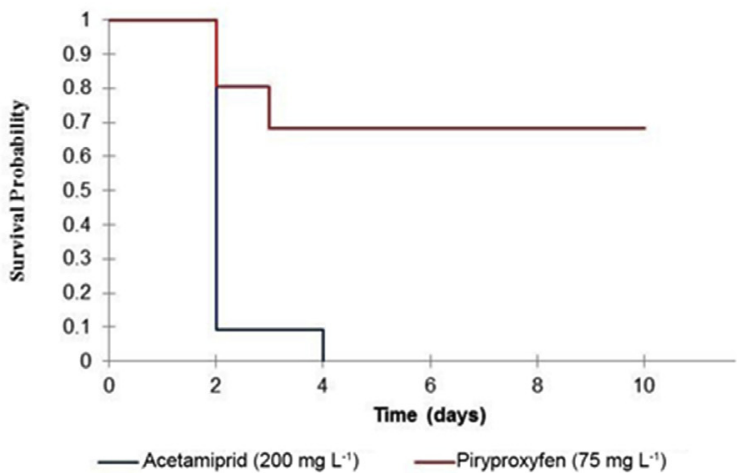

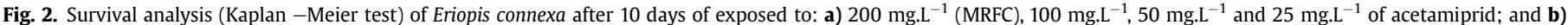

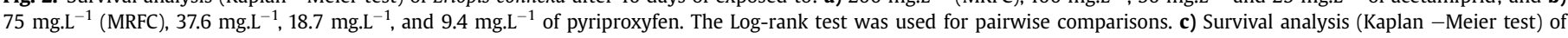

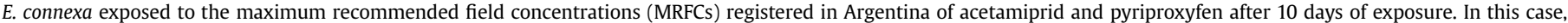
survival data were corrected with control to be possible the comparison.

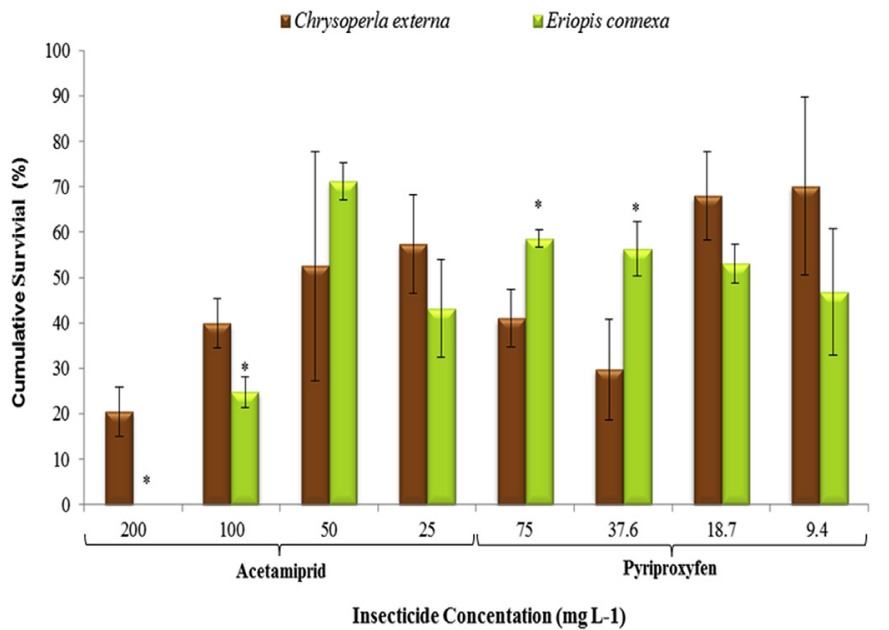

Fig. 3. Cumulative survival of Chrysoperla externa and Eriopis connexa to acetamiprid and pyriproxyfen. The survival data were corrected with control to be possible the comparison. The statistical comparison between species for each treatment was evaluated by the Student and Mann-Whitney test. The data correspond to mean values (means $\pm \mathrm{SEM}$ ). The asterisks $\left({ }^{*}\right)$ indicate significant differences between species.

Rimoldi et al., 2008), certain reports have indicated otherwise. For example, similar to the present results, Chen and Liu (2002) observed toxic effects of pyriproxyfen on the eggs of Chrysoperla rufrilabris Burmeister (Neuroptera: Chrysopidae).

The egg chorion provides physical and chemical protection for the embryo during development, preventing desiccation and the entry of hydrophilic substances (Nation, 2008). Hoffmann et al. (2008) stressed the correlation between the ovicidal effect on the pest Conotrachelus nenuphar Herbst (Coleoptera: Curculionidae) of several neonicotinoid insecticides and their corresponding $\mathrm{K}_{\mathrm{o} / \mathrm{w}}$ values. Kilpatrick et al. (2005) observed that acetamiprid $\left(\log \mathrm{K}_{\mathrm{o}}\right.$ $\mathrm{w}=0.8$ ) caused significant ovicidal effects; whereas imidacloprid $\left(\log \mathrm{K}_{\mathrm{o} / \mathrm{w}}=0.57\right)$, exhibited a lower activity, and compounds like thiamethoxam $\left(\log \mathrm{K}_{\mathrm{o} / \mathrm{w}}=-0.13\right)$ could not reach the target site of the embryo (Smith and Salkeld, 1966). Nevertheless, those same authors themselves cautioned that partitioning coefficients are not absolute predictors of insecticide activity. Taking account these observations, we could hypothesize that the ovicidal effects of acetamiprid in the present study could be directly related to the uptake of the compound by the egg. Moreover, since this insecticide acts on general insect physiologic processes, the low selectivity observed with this pesticide might well be expected.

The higher $\mathrm{K}_{\mathrm{o} / \mathrm{w}}$ of pyriproxyfen ( $\log \mathrm{K}_{\mathrm{o} / \mathrm{w}}=5.37$ ) would predict that the insecticide could surmount the hydrophobic barriers of the chorion, though certain authors have considered that this compound's poor permeability to eggs is owing to the relatively high molecular weight of $321.37 \mathrm{~g} \mathrm{~mol}^{-1}$ (Moscardini et al., 2013). Nevertheless, the mode of action of pyriproxyfen is more specific 

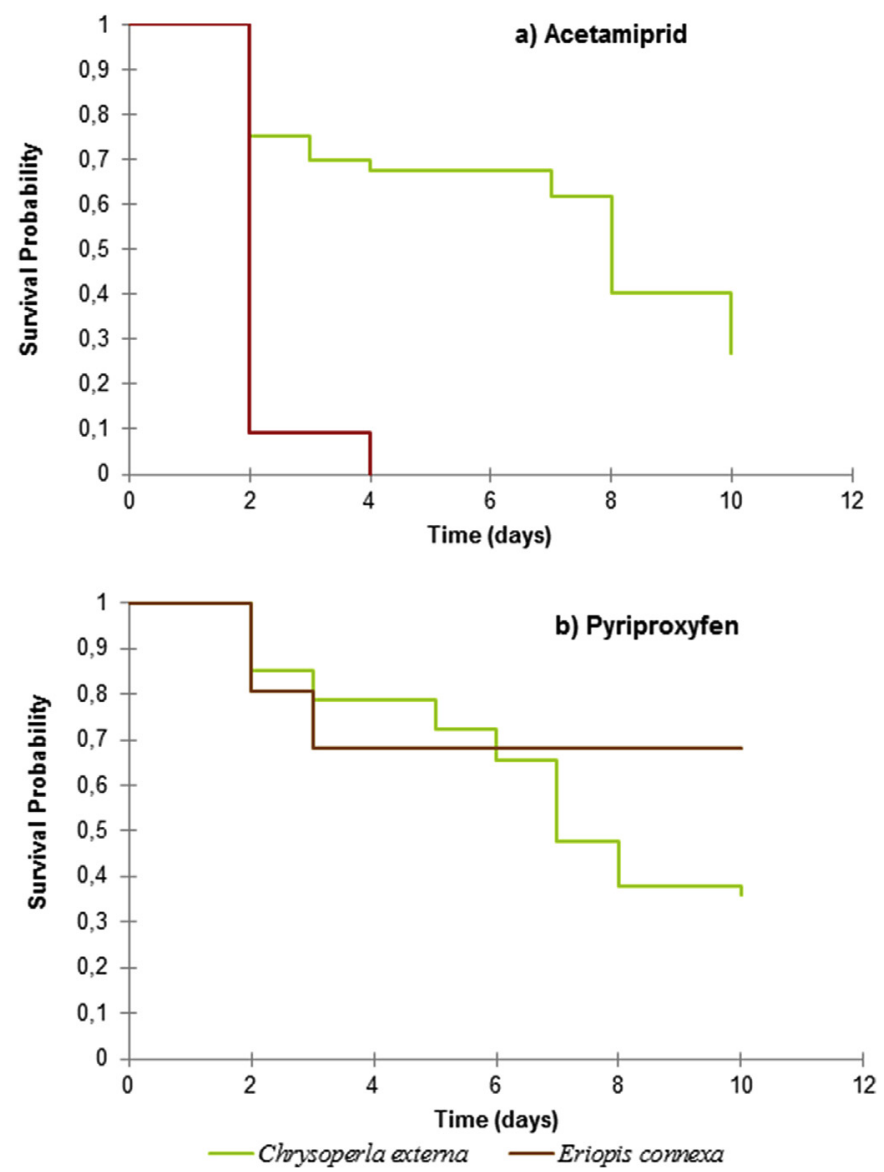

Fig. 4. Comparative survival analysis (Kaplan -Meier test) of Chrysoperla externa and Eriopis connexa exposed to the maximum recommended field concentrations (MRFCs) registered in Argentina of a) acetamiprid ( $\left.200 \mathrm{mg} . \mathrm{L}^{-1}\right)$ and b) pyriproxyfen $\left(75 \mathrm{mg} . \mathrm{L}^{-1}\right)$ along 10 days. Survival data were corrected with control to be possible the comparison.

than that of acetamiprid and depends on the presence of insecticide-specific endocrine receptors in the embryos developing inside of egg (Sullivan and Goh, 2008). These considerations could explain the lack of ovicidal effects of this insecticide on E. connexa. Although the ovicidal effects of this IGR on $C$. externa would best be discussed in view of the particular characteristics of the chorion in different species, the available literature on those details is insufficient to resolve this question; and therefore further research along those lines would be necessary to do so.

\subsection{Effects on the developmental stages after pesticide exposure}

Acetamiprid at $200 \mathrm{mg}$ a.i. $\mathrm{L}^{-1}$ caused a significant impact on the survival of the neonatal larvae of both predators. In $C$. externa, the neonatal larvae were dead upon hatching and were not able to detach from the chorion. Cypermethrin had produced a similar larval mortality after exposure of the eggs in this species (Rimoldi et al., 2008). In order to emerge from the egg, the larvae of C. externa use their mandibles to break the chorion, whereas the neonatal larvae of $E$. connexa have in the head and prothorax a structure referred to as the egg tooth that likewise is believed to play a role in hatching (Nedvěd and Honěk, 2012). In addition, the neonatal larvae of the latter species consume part of the chorion right after hatching. Therefore the effects on the neonatal larvae that were observed could be related to exposure to the insecticide during the act of hatching. The survival of the first larval instar was also affected by the other treatments, but in these instances, the resulting lethality was not detected immediately after hatching so that the larvae were able to emerge completely.

The effects of neonicotinoids on the larvae of the natural enemies have been documented by several authors (Ayuvi et al., 2013; Cloyd and Bethke, 2011; Yao et al., 2015), though the IGRs usually have low larvicidal activity on those beneficial insects (Rill et al., 2008; Rimoldi et al., 2008; Vivek et al., 2012). Notwithstanding, certain authors have reported the opposite result (Biondi et al., 2015; Moscardini et al., 2013; Schneider et al., 2004). In particular, and in keeping with the results of the present study, Rugno et al. (2016) detected adverse effects of pyriproxyfen and other IGRs on the survival of Ceraeochrysa cincta Schneider (Chrysopidae: Neuroptera).

\subsection{Effects on cumulative survival (from the egg to the adult)}

The earliest studies on the compatibility of insecticides with the natural enemies involved short-term assessments (Vivek et al., 2012; Vogt et al., 2000), though more recently the emphasis has shifted to further investigations aimed at revealing long-term impacts that would not be evident over the short term (Dhadialla et al., 1998; Fogel et al., 2013; Rimoldi et al., 2008; Schneider et al., 2009). In the present work, we observed that most of the concentrations of both insecticides investigated reduced the cumulative survival of $C$. externa and $E$. connexa. In general, this reduction was associated with significant effects on the survival of the egg or the first larval instar since the survival of the rest of the larval instars and the pupae were not affected. Nevertheless, in certain instances-such as, for example, at all the concentrations of pyriproxyfen tested on E. connexa-effects on cumulative survival were detected; but without any significant mortality for each developmental stage being observed, thus suggesting that the toxicity in these instances was less immediate and less intense, but longer lasting. This type of response had also been observed for C. externa in previous experiments involving the insecticide spinosad (Rimoldi et al., 2008) as well as for Coccinella septempunctata L. (Coleoptera: Coccinellidae) with hexaflumuron (Yu et al., 2014).

\subsection{Survival analysis}

Survival analyses enable an understanding of how cumulative survival is modified over time. In studies of the compatibility of insecticides with the natural enemies of pests, the technique serves to analyze both the intensity and rapidity of action of the compounds. In the present work, the background of natural deaths in the $C$. externa controls during the first days of the experiment was very low and increased only slightly throughout the rest of the tenday period investigated. None of the treatments appeared to modify the shape of the survival curves substantially. The action of these pesticides affected proportionally the intensity of daily mortality, but not so much the slopes of the survival curves; hence, no noticeable changes were evident in the mean survival time. Therefore, the effects of the two compounds under study on the survival of this species were both concentration-dependent and long-term. This delay in the expression of the mortality observed in C. externa might be explained by a mechanism whereby the insecticides and/or their metabolites accumulate in the tissues of the different stages to then be slowly released within the insect, thus leading to a form of chronic exposure. Sullivan and Goh (2008) referred to a tendency of pyriproxyfen to bioaccumulate because of the insecticide's high $\mathrm{K}_{\mathrm{o} / \mathrm{w}}$, though previous studies had indicated that the compound had a short internal half-life as a result of elimination. For example, it was found a 93\% elimination of pyriproxyfen in fish after two weeks, although Brunet et al. (2005) documented that only $40 \%$ of acetamiprid and its metabolites 
were eliminated from Apis mellifera, thus suggesting substantial persistence after $72 \mathrm{~h}$.

The control survival curve in E. connexa showed an asymptotic negative shape, but the insecticides-mainly acetamiprid-altered the shape of this curve by changing the slope. Thus, in these treatments, the mean survival times were significantly lower, evidencing drastic short-term effects. Youn et al. (2003) also reported the short-term mortality of neonicotinoids on other Coccinellidae species. A comparison of the responses of this species to the two insecticides indicated that the effect of acetamiprid involved a concentration-dependent increase in the killing intensity and the speed of action; whereas, although pyriproxyfen also produced significant toxic effects, the extent of this compound's action was quite similar at all the concentrations tested.

\subsection{Effects on immature developmental time}

Several studies have reported an alteration in the immature developmental period of pest-predatory arthropods in response to pesticide exposure (Desneux et al., 2007; Li et al., 2015; Rimoldi et al., 2008). With the two predators investigated in the present work, we found that some of the concentrations of acetamiprid and pyriproxyfen tested altered the developmental time of the eggs and early larval instars.

Previous studies had reported that exposure to spinosad and cypermethrin caused a shortening of the egg period of $C$. externa (Rimoldi et al., 2008); whereas fenoxycarb and pyriproxyfen had been found to lengthen of the developmental time of eggs in C. rufilabris (Chen and Liu, 2002; Liu and Chen, 2001), as did the action of imidacloprid in the pest predator Apolygus lucorum Meyer-Dur (Hemiptera: Miridae) (Tan et al., 2012). In contrast, Rugno et al. (2016) reported that pyriproxyfen caused no effects on the duration of the larval period in C. cincta, while Li et al. (2015) observed a lengthening of certain larval instars of Serangium japonicum Chapin (Coleoptera: Coccinellidae) after exposure to pyriproxyfen. The juvenile hormone together with 20 hydroxyecdysone regulates the molting and metamorphosis of insects (Nation, 2008). The effects observed on developmental time with pyriproxyfen in the present experiment could be related to alterations in the endogenous levels of the juvenile hormone as a result of the uptake of the juvenoid. Accordingly, certain studies had registered alterations in the time required for the development and metamorphosis of crustaceans that were caused by juvenoids (McKenney, 2005). In contrast, as mentioned above, acetamiprid acts on the insect central nervous system, producing a more generalized alteration in the targeted individual that, as a consequence, potentially affects as well the developmental time.

\subsection{Compatibility between insecticides and the natural enemies of pests: insecticide selectivity and species susceptibility}

A comparison of the differential susceptibility between C. externa and E. connexa to toxicity by the two insecticides under investigation in terms of the species' cumulative survival (from egg to adult) demonstrated that E. connexa was more susceptible to both, since all the treatments significantly affected that parameter; whereas, with the neuropteran predator, only higher concentrations of both insecticides produced deleterious effects. Notwithstanding, if only high concentrations are considered, E. connexa was more susceptible to acetamiprid than $C$. externa, with the relative susceptibility being the reverse for pyriproxyfen.

The evaluation of the relative selectivity of the two insecticides by means of the survival curves after exposure to the MFRCs indicated that pyriproxyfen treatment resulted in a similar cumulative survival at ten days for both predators. Nevertheless, the effects on
C. externa were evident on the long term but on E. connexa on the short term, thus indicating that the mean survival times were different between both species. In this regard, in the example of acetamiprid, the differences in susceptibility between the two pest predators were more evident since $E$. connexa exhibited a more intense and rapid toxicity. Field studies have demonstrated that acetamiprid reduces the densities of several pest predators (Naranjo and Akey, 2005), but Garzón et al. (2015) reported that the insecticide sulfoxaflor caused a greater toxicity to the coccinellid Adalia bipunctata L. (Coleoptera: Coccinellidae) than to C. carnea.

\section{Conclusions}

This work provides relevant data on the significance of evaluating the long-term compatibility between pesticides and natural enemies of pests, in order to avoid an underestimation of potential adverse effects on those beneficial species and compares the relative susceptibility between two relevant Neotropical pest-predator species, thus providing basic information for the selection of these predators for field liberations.

\section{Acknowledgements}

This research was supported by the PICT 0919 project from the Argentinean National Agency for the Promotion of Science and Technology (ANPCyT), and by PIP 0090 and PIP 0205 projects from National Scientific and Technical Research Council (CONICET) granted to AE Ronco and MI Schneider, respectively. Authors wish to thank SummitAgro SA for providing the tested insecticides. English style and grammar was improved by Dr. Donald F. Haggerty, a retired academic career investigator and native English speaker. $\mathrm{F}$ Rimoldi, MN Fogel and MI Schneider feel the loss of AE Ronco, which is mourned by all those lucky to have known her.

\section{References}

Almeida-Sarmento, R., Pallini, A., Venzon, M., Fonseca de Souza, O.F., MolinaRugama, A.J., Lima de Oliveira, C.L., 2007. Functional response of the predator Eriopis connexa (Coleoptera: Coccinellidae) to different prey types. Braz. Arch. Biol. Technol. 50, 121-126.

Ayuvi, A., Moravvej, G., Karimi, J., Jooyandeh, A., 2013. Lethal effects of four insecticides on immature stages of Chrysoperla carnea (Stephens) (Neuroptera: Chrysopidae) in laboratory conditions. Turk. J. Entomol. 37, 399-407.

Biondi, A., Campolob, O., Desneux, N., Siscaro, G., Palmeri, V., Zappalà, L., 2015. Life stage-dependent susceptibility of Aphytis melinus DeBach (Hymenoptera: Aphelinidae) to two pesticides commonly used in citrus orchards. Chemosphere $128,142-147$.

Brunet, J.L., Badiou, A., Belzunces, L.P., 2005. In vivo metabolic fate of [C-14]acetamiprid in six biological compartments of the honeybee, Apis mellifera L. Pest Manag. Sci. 61, 742-748.

Cámara Argentina de Sanidad Agropecuaria y Fertilizantes (CASAFE), 2013/2015. Guía de productos fitosanitarios. CASAFE, Buenos Aires.

Chen, T.Y., Liu, T.X., 2002. Susceptibility of immature stages of Chrysoperla rufilabris (Neuroptera, Chrysopidae) to pyriproxyfen, a juvenile hormone analog. J. Appl. Entomol. 126, 125-129.

Cloyd, R.A., Bethke, J.A., 2011. Impact of neonicotinoid insecticides on natural enemies in greenhouse and interiorscape environments. Pest Manag. Sci. 67, 3-9.

Christen, V., Bachofer, S., Fent, K., 2017. Binary mixtures of neonicotinoids show different transcriptional changes than single neonicotinoids in honeybees (Apis mellifera). Environ. Pollut. 220, 1264-1270.

Dhadialla, T.S., Carlson, G.R., Le, D.P., 1998. New insecticides with ecdysteroidal and juvenile hormone activity. Annu. Rev. Entomol. 43, 545-556.

Desneux, N., Decourtye, A., Delpuech, J.M., 2007. The sublethal effects of pesticides on beneficial arthropods. Annu. Rev. Entomol. 52, 81-106.

European Commission, 2009. Directive 2009/128/EC of the European parliament and the council ok 21 October 2009 establishing a frame work for community action to archive sustainable use of pesticides. Off. J. Eur. Union 309, 71-86.

Food and Agriculture Organization of the United Nations (FAO-WHO), 2013. International Code of Conduct on the Distribution and Use of Pesticides. Guidelines on data requirements for the registration of pesticides, Rome, Italy.

Ferreira, A.J., Carvalho, G.A., Botton, M., Mendoza, L.A., Correa, A.R.B., 2005. Selectividade de inseticidas na cultura da macieira a ovos de Chrysoperla externa (Hagen, 1861) (Neuroptera: Chrsopidae). Cienc. Rural. 35, 756-762.

Fogel, M.N., 2012. Selectividad de insecticidas utilizados en cultivos hortícolas del 
Cinturón Hortícola Platense sobre el depredador Eriopis connexa en el marco del Manejo Integrado de Plagas. Tesis Doctoral. Facultad de Ciencias Exactas, Universidad Nacional de La Plata, La Plata.

Fogel, M.N., Schneider, M.I., Desneux, N., Gonzalez, B., Ronco, A.E., 2013. Impact of the neonicotinoid acetamiprid on immature stages of the predator Eriopis connexa (Coleoptera: Coccinellidae). Ecotoxicology 22, 1063-1071.

Fogel, M.N., Schneider, M.I., Rimoldi, F., Ladux, L.S., Desneux, N., Ronco, A.E., 2016. Toxicity assessment of four insecticides with different modes of action on pupae and adults of Eriopis connexa (Coleoptera: Coccinellidae), a relevant predator of the Neotropical Region. Environ. Sci. Pollut. Res. 23, 14918-14926.

Garzón, P., Medina, F., Amor, E., Viñuela, E., Budia, F., 2015. Toxicity and sublethal effects of six insecticides to last instar larvae and adults of the biocontrol agents Chrysoperla carnea (Stephens) (Neuroptera: Chrysopidae) and Adalia bipunctata (L.) (Coleoptera: Coccinellidae). Chemosphere 132, 87-93.

Ghanim, M., Ishaaya, I., 2010. Insecticides with novel modes of action: mechanism and resistance management. In: Ishaaya, I., Degheele, D. (Eds.), Insecticides with Novel Modes of Action: Mechanism and Application. Springer, Berlin, pp. 385-407.

Guedes, R.N., Smagghe, G., Stark, J.D., Desneux, N., 2016. Pesticide-induced stress in arthropod pests for optimized integrated pest management programs. Annu. Rev. Entomol. 61, 43-62.

Haramboure, M., Mirande, L., Schneider, M.I., 2016. Improvement of the mass rearing of larvae of the neotropical lacewing Chrysoperla externa through the incorporation of a new semiliquid artificial diet. BioControl 61, 69-78.

He, Y.X., Zhao, J., Zheng, Y., Zhan, Z., Desneux, N., Wu, K.M., 2012. Lethal effect of imidacloprid on the coccinellid predator Serangium japonicum and sublethal effects on predator voracity and on functional response to the whitefly Bemisia tabaci. Ecotoxicology 21, 1291-1300.

Hoffmann, E.J., Middleton, S.M., Wise, J.C., 2008. Ovicidal activity of organophosphate, oxadiazine, neonicotinoid and insect growth regulator chemistries on northern strain plum curculio, Conotrachelus nenuphar. J. Insect Sci. 8, 1-6.

Ishaaya, I., Barazani, A., Kontsedalov, S., Horowitz, A.R., 2007. Insecticides with novel modes of action: mechanism, selectivity and cross-resistance. Entomol. Res. 37, $148-152$.

Jacas, J., Urbaneja, A., 2009. Origen de las plagas e historia del Control Biológico. In: Jacas, J., Urbaneja, A. (Eds.), Control Biológico de Plagas Agrícolas. Phytoma, España, pp. 3-13.

Kilpatrick, A.L., Hargerty, A.M., Turnipseed, S.G., Sullivan, M.J., Bridges, W.C., 2005. Activity of selected neonicotinoids and dicrotophos on nontarget arthropods in cotton: implications in insect management. J. Econ. Entomol. 98, 814-820.

Li, P., Chen, Q., Liu, T., 2015. Effects of a juvenile hormone analog, pyriproxyfen, on Serangium japonicum (Coleoptera: Coccinellidae), a predator of Bemisia tabaci (Hemiptera: Aleyrodidae). Biol. Control 86, 7-13.

Liu, T.X., Chen, T.Y., 2001. Effects of the insect growth regulator fenoxycarb on immatures of Chrysoperla rufilabris (Neuroptera, Chrysopidae). Fla. Entomol. 84, 628-633.

Malagnoux, L., Capowiez, Y., Rault, M., 2015. Impact of insecticide exposure on the predation activity of the european earwig Forficula auricularia. Environ. Sci. Pollut. Res. 22, 14116-14126.

McKenney, C.L., 2005. The influence of insect juvenile hormone agonists on metamorphosis and reproduction in estuarine crustaceans. Integr. Comp. Biol. 45, 97-105.

Medina, P., Budia, P.F., Del Estal, P., Viñuela, E., 2003. Effect of three modern insecticides, pyriproxyfen, spinosad and tebufenozide, on survival and reproduction of Chrysoperla carnea adults. Ann. Appl. Biol. 142, 55-61.

Mirande, L., 2016. Aspectos bioecológicos de Harmonia axyridis (Coleóptera: Coccinelidae), con especial énfasis en la susceptibilidad de insecticidas: implicancias a nivel ecológico. Tesis Doctoral. Facultad de Ciencias Naturales y Museo, Universidad Nacional de La Plata, La Plata.

Moscardini, V.F., Da Costa Gontijo, P., Carvalho, G.A., Lopes de Oliveira, R., Jader Braga, M., Silva, F.F., 2013. Toxicity and sublethal effects of seven insecticides to eggs of the flower bug Orius insidiosus (Say) (Hemiptera: Anthocoridae). Chemosphere 92, 490-496.

Naranjo, S.E., Akey, D.H., 2005. Conservation of natural enemies in cotton: comparative selectivity of acetamiprid in the management of Bemisia tabaci. Pest Manag. Sci. 61, 555-566.

Nation, J.L., 2008. Reproduction. In: Nation, J.L. (Ed.), Insect Physiology and Biochemistry. CRC Press, Florida, pp. 497-498.

Nedvěd, O., Honěk, A., 2012. Life history and development. In: Hodek, I., van Emden, H.F., Honěk, A. (Eds.), Ecology and Behavior of Ladybirds Beetles (Coccinellidae). Wiley Blackwell, United Kingdom, pp. 54-56.

Nuñez, E., 1998. Ciclo biológico y crianza de Chrysoperla externa y Ceraeochrysa cincta (Neuroptera, Chrysopidae). Rev. Peru. Entomol. 31, 76-82.

Rill, S.M., Grafton-Cardwell, E.E., Morse, J.G., 2008. Effects of two insect growth regulators and a neonicotinoid on various life stages of Aphytis melinus (Hymenoptera: Aphelinidae). BioControl 53, 579-587.

Rimoldi, F., Schneider, M.I., Ronco, A.E., 2008. Susceptibility of Chrysoperla externa eggs (Neuroptera: Chrisopidae) to conventional and biorational insecticides. Environ. Entomol. 37, 1252-1257.

Rimoldi, F., 2009. Evaluación ecotoxicológica de plagucidas usados en el paquete tecnológico Soja RR, sobre el sistema Rachiplusia nu-Chrysoperla externa. Tesis Doctoral. Facultad de Ciencias Exactas, Universidad Nacional de La Plata, La Plata.

Rimoldi, F., Schneider, M.I., Ronco, A.E., 2012. Short and Long-term effects of endosulfan, cypermethrin, spinosad, and methoxyfenozide on adults of Chrys operla externa (Neuroptera: Chrysopidae). J. Econ. Entomol. 105, 1982-1987.

Rodrigues Barbosa, L., de Carvahlo, C.F., Souza, B., Machado Auad, A., 2008. Efficiency of Chrysoperla externa (Hagen, 1861) (Neuroptera: Chrysopidae) in the Myzus persicae (Sulzer, 1776) (Hemiptera: Aphididae) population reduction in sweet pepper (Capsicum annum L.). Ciência Agrotecnol. 32, 1113-1119.

Ronco, A.E., Carriquiriborde, P., Natale, G.S., Martin, M.L., Mugni, H., Bonetto, C., 2008. Integrated approach for the assessment of biotech soybean pesticides impact on low order stream ecosystems of the Pampasic Region. In: Chen, J. Guo, C. (Eds.), Ecosystem Ecology Research. Nova Science Publishers, New York, pp. 209-239.

Rugno, G.R., Zanuzo Zanardi, O., Bajonero Cuervo, J., Rovere de Morais, M., Takao Yamamoto, P., 2016. Impact of insect growth regulators on the predator Ceraeochrysa cincta (Schneider) (Neuroptera: Chrysopidae). Ecotoxicology 25, 940-949.

Sánchez-Bayo, F., 2011. Impacts of agricultural pesticides on terrestrial ecosystems. In: Sánchez-Bayo, F., van den Brink, P.J., Reinier, R.M. (Eds.), Ecological Impacts of Toxic Chemicals. Bentham Science Publishers Ltd., USA, pp. 63-87.

Schneider, M.I., Smagghe, G., Pineda, S., Viñuela, E., 2004. Action of insect growth regulator insecticides and spinosad on life history parameters and absorption in third instar larvae of the endoparasitoid Hyposoter didymator. Biol. Control 31, 189-198.

Schneider, M.I., Sanchez, N., Pineda, S., Chi, H., Ronco, A., 2009. Impact of glyphosate on the development, fertility and demography of Chrysoperla externa (Neuroptera: Chrysopidae): ecological approach. Chemosphere 76, 1451-1455.

Smith, E.H., Salkeld, E.H., 1966. The use and action of ovicides. Annu. Rev. Entomol. $11,331-368$.

Silva, R.A., Carvalho, G.A., Carvalho, C.F., Silva, D.B., 2012. Effects of pesticides on eggs of Chrysoperla externa (Neuroptera: Chrysopidae) and consequences on subsequent development. Rev. Colomb. Entomol. 38, 58-63.

Symondson, W.O., Sunderland, K.D., Greenstone, M.H., 2002. Can generalist predators be effective biocontrol agents? Annu. Rev. Entomol. 47, 561-594.

Sullivan, J., Goh, S., 2008. Environmental fate and properties of pyriproxyfen. J. Pestic. Sci. 33, 339-350.

Tan, Y., Biondi, A., Desneux, N., Gao, X.W., 2012. Assessment of physiological sublethal effects of imidacloprid on the mirid bug Apolygus lucorum (Meyer-Dür) Ecotoxicology 21, 1989-1997.

Tomizawa, M., Casida, J.E., 2005. Neonicotinoid insecticide toxicology: mechanisms of selective action. Annu. Rev. Pharmacol. Toxicol. 45, 247-268.

United States Environmental Protection Agency (USEPA), 2015. http://www.epa.org. Accessed 27 October 2015.

Vivek, S., Bishwajeet, P., Pirasanna, P.G.G., Shankarganesh, K., 2012. Relative toxicity of insecticides on larval stages of green lacewing, Chrysoperla sp. (Carneagroup) (Chrysopidae: neuroptera). Indian J. Entomol. 74, 394-397.

Vogt, H., Bigler, F., Brown, K., Candolfi, M.P., Kemmeter, F., Kühner, Ch., Moll, M. Travis, A., Ufer, A., Viñuela, E., Waldburger, M., Waltersdorfer, A., 2000. Laboratory method to test effects of plant protection products on larvae of Chrysoperla carnea (Neuroptera: Chrysopidae). In: Candolfi, M.P., Blümel, S., Forster, R., Bakker, F.M., Grimm, C., Hassan, S.A., Heimbach, U., Mead-Briggs, B. Reber, R., Schmuck, R., Vogt, H. (Eds.), Guidelines to Evaluate Side-effects of Plant Protection Products to Non-target Arthropods. IOBC/WPRS, pp. 27-44.

XLSTAT, 2009. XLstat for Excel, Ver. 7.5. Addinsoft, United Kingdom.

Yao, F.L., Zheng, Y., Zhaoa, J.W., Desneux, N., Hea, Y.X., Weng, Q.Y., 2015. Lethal and sublethal effects of thiamethoxam on the whitefly predator Serangium japonicum (Coleoptera: Coccinellidae) through different exposure routes. Chemosphere 128, 49-55.

Youn, Y.N., Seo, M.J., Shin, J.G., Jang, C., Yub, Y.M., 2003. Toxicity of greenhouse pesticides to multicolored Asian lady beetles, Harmonia axyridis (Coleoptera: Coccinellidae). Biol. Control 28, 164-170.

Yu, C., Lin, R., Fu, M., Zhou, Y., Zong, F., Jiang, H., Lv, N., Piao, X., Zhang, J., Liu, Y., Brock, T.C.M., 2014. Impact of imidacloprid on life-cycle development of Coccinella septempunctata in laboratory microcosms. Ecotoxicol. Environ. Saf. 110, 168-173. 